\title{
Koncepcja pozyskania litu ze złóż wód termalnych z wykorzystaniem technologii membranowych
}

\author{
Karol M. Dąbrowski ${ }^{1}$ (D), Michał Zając ${ }^{1}$ (D), Katarzyna A. Kozieł² (D) \\ 1 AGH Akademia Górniczo-Hutnicza, Wydział Wiertnictwa, Nafty i Gazu, Kraków \\ 2 Instytut Mechaniki Górotworu PAN, Kraków
}

\begin{abstract}
Streszczenie: Rozwój technologii transportu elektrycznego rodzi zwiększone zapotrzebowanie na rzadkie pierwiastki, w tym lit, który jest niezbędnym surowcem do produkcji akumulatorów. W pracy scharakteryzowano obecne metody pozyskiwania litu. Porównano te metody pod kątem kosztów oraz opłacalności. Przedstawiono charakterystykę światowego oraz europejskiego rynku litu oraz omówiono perspektywy, jak również ograniczenia jego rozwoju. Zaproponowano metodę pozwalającą na rozwój krajowej produkcji litu z wykorzystaniem złóż geotermalnych. Znaczące ilości litu ze złóż geotermalnych mogą być odzyskane dzięki bardzo dużym przepływom solanki (ponad $200 \mathrm{~m}^{3} / \mathrm{h}$ ) oraz dużemu udziałowi jonów tego pierwiastka w roztworze (ponad $260 \mathrm{mg} / \mathrm{l}$ ). Oszacowano możliwą produkcję litu z istniejących instalacji geotermalnych oraz przedstawiono scenariusze opłacalności ewentualnego wdrożenia.
\end{abstract}

Słowa kluczowe: lit, geotermia, surowce mineralne, zrównoważony rozwój, membrany

\section{THE CONCEPT OF LITHIUM PRODUCTION FROM THERMAL WATER DEPOSITS WITH THE USE OF MEMBRANE TECHNOLOGIES}

\begin{abstract}
The development of electric transport technology creates an increased demand for rare elements, including lithium, which is an essential raw material for the production of batteries. The present study describes the current methods of obtaining lithium. These methods were compared in terms of cost and cost-effectiveness. The characteristics of the global and European lithium market are presented and the prospects and limitations of its development are discussed. A method has been proposed that allows for the development of domestic lithium production based on geothermal deposits. Recovering significant amounts of lithium from geothermal deposits can be achieved thanks to very high brine flows (over $200 \mathrm{~m}^{3} / \mathrm{h}$ ) and a significant share of this element's ions in the solution (over $260 \mathrm{mg} / \mathrm{L}$ ). Possible lithium production was estimated based on the existing geothermal installations and scenarios of profitability or implementation were presented.
\end{abstract}

Keywords: lithium, geothermal, mineral resources, sustainable development, membranes

https://doi.org/10.7494/978-83-66727-48-9_3 


\section{Wstęp}

Lit został umieszczony na liście krytycznych surowców UE, a uzależnienie Wspólnoty od jego importu wynosi 100\% (Bobba i in. 2020). Główne kraje dostarczające ten surowiec to Chile (posiadające 78\% udziałów w rynku), Stany Zjednoczone i Rosja (Bobba i in. 2020). Unia Europejska zużywa około 6000 t litu rocznie, jednocześnie do roku 2030 ilość ta ma wzrosnąć 18-krotnie (do 108000 t), zaś zużycie tego surowca w roku 2050 ma wynieść 60-krotność konsumpcji w 2020 (ok. 360000 t). Szacunkowa wartość importowanego surowca wzrośnie od około 60 mln USD w roku 2020 do około 3,6 mld USD w roku 2050, według średnich cen transakcyjnych z 2020 (Bobba i in. 2020). Na rynku polskim zapotrzebowanie na lit w roku 2020 wyniosło ponad 314 t LCE (lithium carbonate equivalent) o łącznej wartości przekraczającej 11,5 mln PLN (GUS 2021). Do głównych odbiorców tego surowca należą producenci akumulatorów, szkła i ceramiki, stali, aluminium, smarów oraz polimerów (Li i in. 2019).

Obecnie wyróżnia się dwa istotne przemysłowo sposoby pozyskania litu. Należy do nich pozyskanie litu z minerałów zawartych w skałach (głównie jest to spodumen) oraz wykorzystanie solanek zasobnych w ten pierwiastek (Flexer i in. 2018). Pierwszy proces polega na kruszeniu i ogrzewaniu skał. Wysoka temperatura wpływa na zmianę układu krystalograficznego, co umożliwia zastąpienie jonów litu jonami sodu. Następnie surowiec jest chłodzony, rozdrabniany, traktowany kwasem siarkowym i prażony. Ponowny kontakt z wodą sprawia, że lit przechodzi do roztworu, a mieszanina jest filtrowana. Następnie z roztworu usuwane są jony magnezu i wapnia. Powstały roztwór jest ponownie oczyszczany z osadów i traktowany węglanem sodu w celu wytrącenia produktu końcowego. Czystość tak uzyskanego węglanu litu wynosi ok. 99\%. Koszt uzyskania $1 \mathrm{t}$ węglanu litu w tym procesie wynosi średnio 2,54 tys. USD.

Drugim istotnym źródłem litu są zasobne w ten pierwiastek solanki, stanowiące największą bazę surowcową na świecie (ok. 80\% światowych zasobów) dla tego komponentu, jednocześnie występujące tylko na terenie trzech państw: Argentyny, Boliwii i Chile. Proces pozyskania litu z tego typu złóż polega na przepompowaniu solanki do płytkich basenów na powierzchni ziemi. Energia słoneczna oraz wiatr powodują odparowanie znacznych ilości wody. Proces takiego zatężania prowadzi się aż do uzyskania koncentracji litu na poziomie 6000 ppm. Uzyskany koncentrat kierowany jest do instalacji produkcyjnej, gdzie usuwa się zbędne składniki, które wcześniej nie wykrystalizowały, tj. borany, kationy magnezu etc. Następnie wytrącany jest węglan litu z wykorzystaniem węglanu sodu. W celu osiągnięcia zadowalającej czystości produktu węglan litu jest wielokrotnie rozpuszczany, przemywany i wytrącany. Koszt uzyskania $1 \mathrm{t}$ węglanu litu w tym procesie wynosi średnio 5,58 tys. USD.

Ze względu na rosnące zapotrzebowanie na lit, brak możliwości dywersyfikacji dostaw oraz wysokie ceny podjęto również próby wykorzystania zasobów tego pierwiastka 
o znacząco niższej koncentracji niż w standardowym podejściu. Do głównych metod, które dotychczas wykorzystywano, należą: wymiana jonowa, elektrodializa (Yaroshchuk $\mathrm{i}$ in. 2019), adsorpcja oraz szeroko pojęte procesy oparte na membranach, takie jak nanofiltracja (Bi i in. 2014, Sun i in. 2015), odwrócona osmoza (Li J. i in. 2018) oraz destylacja membranowa (perwaporacja) (Li X. i in. 2019). Obecnie żadna z wymienionych metod nie jest stosowana w skali przemysłowej do pozyskiwania litu. Trwają natomiast prace doświadczalne mające na celu opracowanie efektywnego procesu odzysku litu z wód termalnych. Przykładowo we Francji powstało konsorcjum, które w maju 2021 uruchomiło pierwszą instalację pilotową w Rittershoffen. Proces odzysku surowca opiera się na absorpcji litu. Szczegóły projektu są przedstawione na stronie konsorcjum (EuGeLi 2021). Podobnie w Niemczech uniwersytet w Karlsruhe prowadzi prace nad stworzeniem własnej instalacji pilotowej do odzysku litu opartej na technologii membranowej. Opis prac przedstawia raport na stronie uniwersytetu (Karlsruhe Institute of Technology 2020).

\section{Analiza rynku litu}

Obecnie lit stał się jednym z najistotniejszych materiałów. Odgrywa ważną rolę w rozwijaniu gospodarki niskoemisyjnej. Wiodącym konsumentem litu jest branża akumulatorów, stanowiąca 65\% światowego rynku litu (Koning i in. 2018). Produkcja baterii stała się kluczowym procesem w globalnym łańcuchu dostaw litu. Pojazdy elektryczne (EV) obejmują większość rynku akumulatorów. Rynek ten zanotował w ostatnich latach znaczący wzrost. Od 25000 t ekwiwalentu węglanu litu (LCE) w 2015 roku do 205000 t LCE, w roku 2025, według Deutsche Bank (Hocking i in. 2016). Swiss Resource Capital podaje przewidywany wzrost z 25760 t LCE w 2015 roku do 202920 t LCE w 2025 roku (Hummel i in. 2017). Jest to spowodowane wzrostem liczby pojazdów elektrycznych. Obecnie głównymi producentami litu są Australia oraz Chile (tab. 1).

Tabela 1

Czołowi producenci litu oraz związków litu

\begin{tabular}{|l|c|c|c|}
\hline \multicolumn{1}{|c|}{ Kraj } & $2018[\mathrm{t}]$ & $2019[\mathrm{t}]$ & Zasoby $[\mathrm{t}]$ \\
\hline Australia & 58800 & 42000 & 2800000 \\
\hline Chile & 17000 & 18000 & 8600000 \\
\hline Chiny & 7100 & 7500 & 1000000 \\
\hline Argentyna & 6400 & 6400 & 1700000 \\
\hline Cały świat & 95000 & 77000 & 17000000 \\
\hline
\end{tabular}

Źródło: dane na podstawie Jaskula (2020) 
Węglan litu stanowi główny surowiec do produkcji ogniw, Chile odpowiada za 44\% jego podaży, Australia za 32\%, a Argentyna za 11\% (European Commission 2018). W UE lit jest produkowany w Portugalii, która odpowiada za 11\% podaży. Zatem lit jest praktycznie w całości importowany do UE z krajów trzecich. Chile odpowiada za 66\% importu, natomiast USA za 9\% (European Commission 2018). W ostatnich latach obserwuje się znaczący wzrost cen litu (tab. 2).

Tabela 2

Zmiana cen litu na przestrzeni lat

\begin{tabular}{|l|c|c|c|c|c|}
\hline Rok & 2015 & 2016 & 2017 & 2018 & 2019 \\
\hline Cena $[$ USD/t] & 6500 & 8650 & 15000 & 17000 & 13000 \\
\hline
\end{tabular}

Źródło: dane na podstawie Jaskula (2020)

Globalny rynek litu jest więc wart przeszło 1 mld USD (Jaskula 2020). Natomiast wartość importu do Polski to ponad 11,5 mln PLN nie uwzględniając kosztów transportu. W roku 2020 sprowadzono ok. $162 \mathrm{t}$ węglanu litu i 172 tlenku i wodorotlenku litu (GUS 2021).

Głównym problemem pozyskiwania litu ze źródeł solankowych jest stosunkowo niski stopień odzysku litu (ok. 30\%), potrzeba oczyszczenia solanki oraz strącania osadów przy pomocy chemikaliów. Główny produkt procesu stanowi węglan litu. Z kolei produkt wydobywany konwencjonalne jest przerabiany na koncentrat i następnie transportowany do zakładów dokonujących jego konwersji. Ze względu na wysokie koszty osobowe w Australii zakłady te znajdują się głównie w Azji. Na rysunku 1 przedstawiono składowe kosztów w poszczególnych metodach ekstrakcji litu. Koszt produkcji z solanek jest około dwa razy większy niż w kopalniach.

Produkcja w kopalniach jest tańsza w porównaniu z pozyskiwaniem litu ze złóż solankowych. Ostateczna marża jest jednak wyższa w przypadku produkcji litu w złożach solankowych. Wynika to z niższej ceny koncentratu spodumenu w stosunku do węglanu, chlorku czy wodorotlenku litu, które są wytwarzane z solanki. Różnicę w cenie poszczególnych produktów przedstawia rysunek 2. Przykładowo cena koncentratu w 2019 roku była średnio 57\% niższa niż węglanu. Różnice w cenie wynikają z kosztów konwersji koncentratu. Przy kształtowaniu ceny istotny jest nie tylko typ produktu, ale również jego jakość. Przykładowo ceny węglanu litu oscylowały w zakresie od 8,5 tys. do 12,5 tys. USD/t LCE w zależności od jakości produktu (S\&P Global Market Intelligence 2021). Różnice te utrudniają końcową analizę kosztów oraz opłacalności. Jednak na podstawie danych można oszacować, że spodziewana marża dla złóż solankowych wyniesie 5 tys. USD/t LCE przy marży 2,5 tys. USD/t dla złóż spodumenu (S\&P Global Market Intelligence 2021). Zatem w każdym z rozpatrywanych przypadków lit stanowi 
produkt wysokomarżowy, co jest argumentem za zasadnością prowadzenia badań oraz inwestycji związanych ze zwiększeniem wydobycia bądź odzysku tego surowca (Hummel i in. 2017, European Commission 2018)

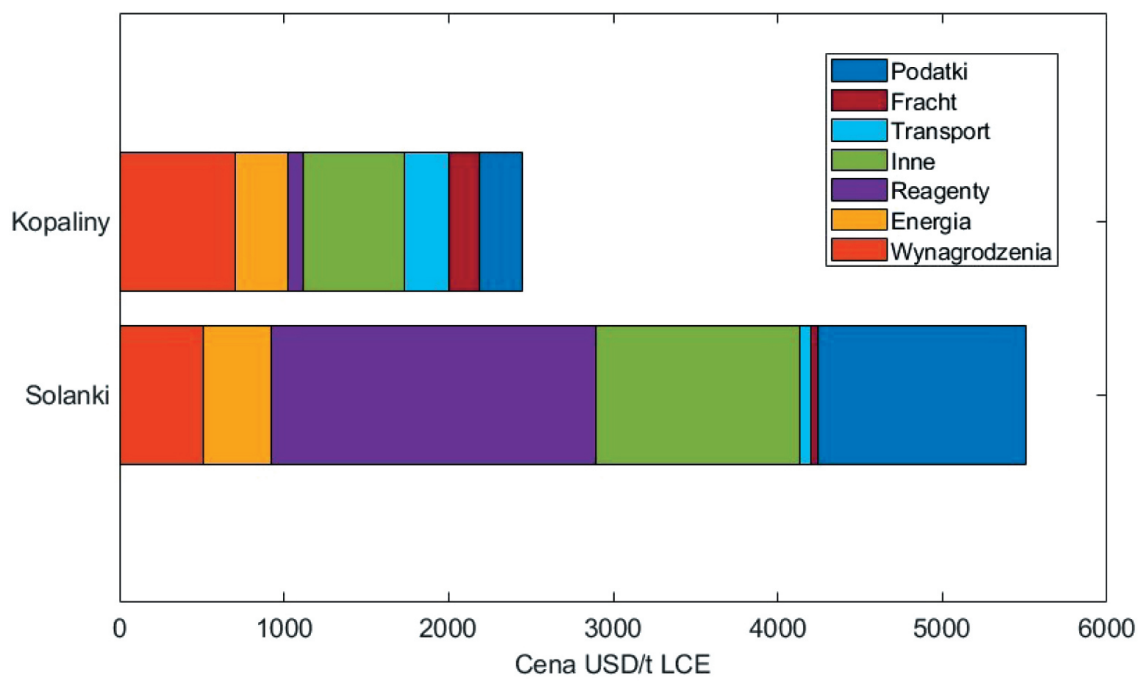

Rys. 1. Główne koszy procesu produkcji litu [USG/t LCE]. W metodzie ekstrahowania z solanki główne koszty stanowią reagenty do oczyszczania solanki, transport oraz opłaty licencyjne, a w przypadku kopalin - koszty osobowe oraz transport Źródło: opracowanie własne za S\&P Global Market Intelligence (2021)

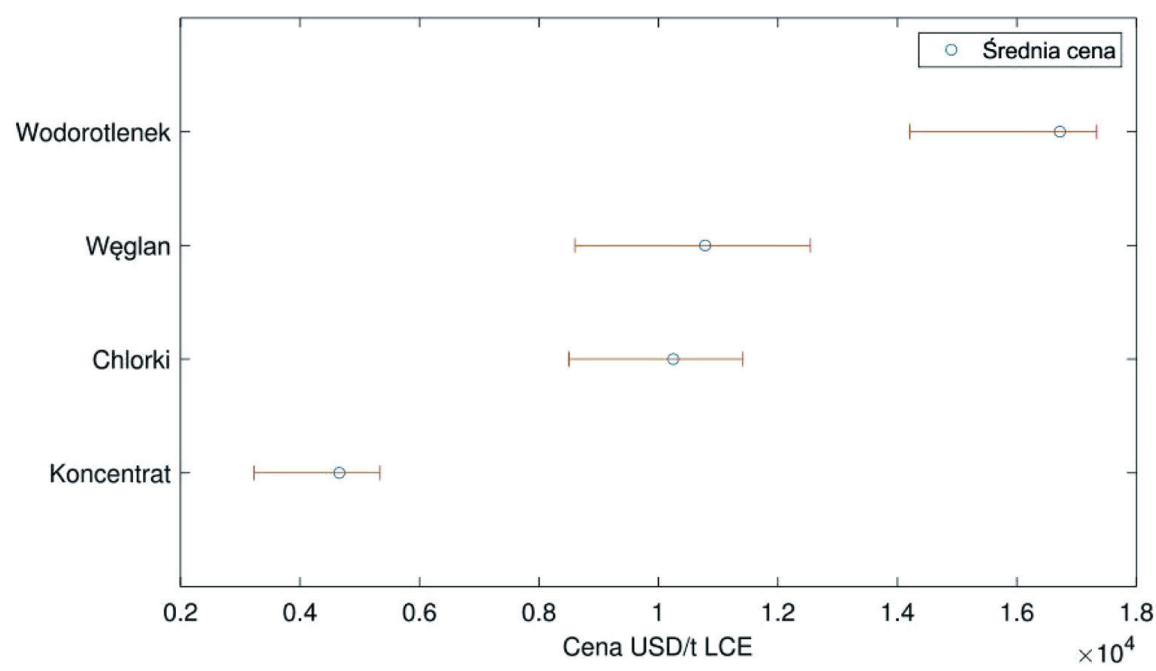

Rys. 2. Średnie ceny poszczególnych związków litu. Najniższą cenę ma koncentrat produkowany w konwencjonalnych kopalniach, znacznie wyższą natomiast chlorek, węglan litu wytwarzany z solanek oraz wodorotlenek litu wytwarzany w zakładach konwersji koncentratu Źródło: opracowanie własne na podstawie S\&P Global Market Intelligence (2021) 
Kolejne zagadnienie stanowi potencjalny wzrost zapotrzebowania na lit oraz jego związki. Jest to kluczowe dla opłacalności i celowości opracowania nowych technologii pozyskiwania litu. Według prognoz w ciągu najbliższych 5 lat zapotrzebowanie na lit oraz jego globalna produkcja wzrosną o 40\% (European Commission 2018). Prognozy pokazują, że światowe zapotrzebowanie na lit może sięgnąć $930 \mathrm{kt}$ do nawet $1750 \mathrm{kt}$ (S\&P Global Market Intelligence 2021). W drugiej połowie lat 20. popyt zacznie znacząco przewyższać podaż, co będzie wpływać na wyższą presję cenową.

Największy wpływ na wzrost zapotrzebowania na lit będzie miał rozwój rynku samochodów elektrycznych oraz elektroniki (rys. 3). Przeważający udział w popycie będą miały akumulatory montowane w samochodach. Natomiast w ciągu 20 lat wzrost zapotrzebowania jest szacowany na 400\% (European Commission 2018).

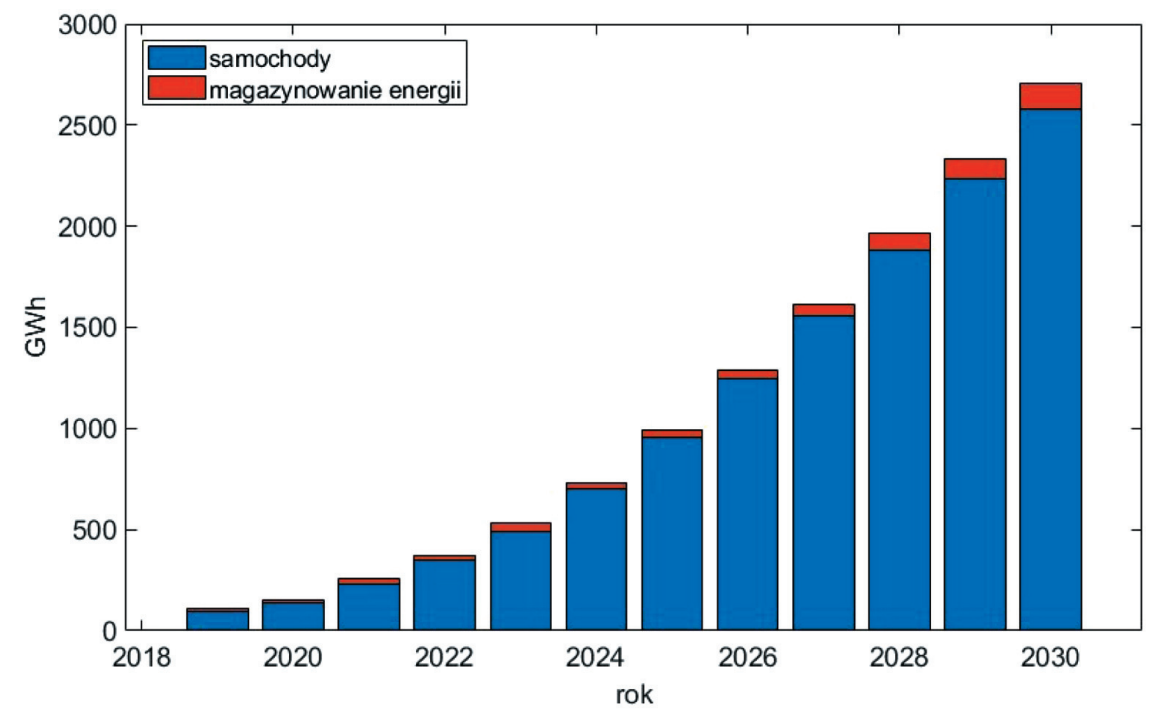

Rys. 3. Wzrost zapotrzebowania na akumulatory dla transportu oraz magazynowania energii wg UBS Evidence Lab

Źródło: opracowanie własne na podstawie Hummel i in. (2017)

Ze względu na wzrost zapotrzebowania na baterie trwa rozbudowa zakładów produkcyjnych. Obecnie firma LG Chem prowadzi w Kobierzycach k. Wrocławia budowę fabryki baterii do samochodów. Będzie to pierwsza tego typu fabryka w Polsce, która może być potencjalnym odbiorcą gotowego produktu. Obecnie lit nie jest surowcem strategicznym w regulacjach prawnych. Mimo to kładzie się nacisk na przyszły rozwój produkcji wewnątrz Wspólnoty (w Austrii i Finlandii) (European Commission 2018) oraz na rozwój odzysku surowców. Przykładowo prowadzony jest projekt H2020 CROCODILE mający na celu rozwój technologii odzyskiwania kobaltu. Pomimo planowanych inwestycji zwiększających wydobycie (European Commission 2018) według szacunków podaż nie będzie nadążać za wzrostem popytu. 
Opracowanie nowych technologii pozyskiwania litu może umożliwić produkcję litu w Polsce. Rodzima produkcja pozwoliłaby na obniżenie kosztów jego zakupu. Ponieważ lit jest importowany do UE m.in. z krajów trzecich, podlega ocleniu w wysokości 5,5\%. Produkcja rodzima może skrócić łańcuch dostaw. Jak pokazano na rysunku 1, kosz transportu wynosi w przybliżeniu 1 tys. USD/t LCE, zatem stanowi ok. 16\% całkowitych kosztów produkcji. Zatem produkt wytworzony w Polsce ma istotną przewagę cenową nad produktem importowanym. Produkcja rodzima pozwoli także na uniezależnienie się od zewnętrznych dostawców oraz dywersyfikację dostaw, co dodatnio wpłynie na płynność i stabilność dostaw (Calisaya-Azpilcueta i in. 2020).

\section{Perspektywy rozwoju polskiej produkcji litu}

Polska ma znaczący potencjał produkcyjny litu z wód termalnych (Uliasz-Misiak i Winid 2018). Obecnie jednak ceny litu są zbyt niskie, by opłacalna była budowa instalacji przeznaczonych specjalnie do jego pozyskiwania. Dlatego układ do odzyskiwania litu musi stanowić infrastrukturę towarzyszącą istniejącym lub planowym odwiertom geotermalnym służącym do celów ciepłowniczym. W takim przypadku produkcja litu może stanowić dodatkowe źródło dochodu operatorów sieci geotermalnej. Aktualnie w Polsce działa sześć ciepłowni geotermalnych na Podhalu oraz na Niżu Polskim: w Mszczonowie, Uniejowie, Poddębicach, Pyrzycach i Stargardzie. Dodatkowo wody geotermalne są wykorzystywane w uzdrowiskach oraz basenach. Przykładowo potencjał produkcyjny węglanu litu w nowo budowanej geotermii Toruń na odwiercie TG-1 tego odwiertu przy zakładanym docelowym przepływie wody wynosi 35 t/ LCE rocznie, co stanowi $20 \%$ obecnego polskiego zapotrzebowania na węglan litu. Przyjmując dolną granicę oszacowania z rysunku 2, czyli 14 tys. USD/t LCE, wartość produkcji można oszacować na około 500 tys. USD/rok.

Wraz z dalszym rozwojem energetyki geotermalnej będzie również się rozwiał potencjał produkcyjny oparty na zaproponowanym rozwiązaniu. Ze względu na aktualną politykę klimatyczną oraz zobowiązania międzynarodowe udział energii pozyskiwanej ze źródeł odnawialnych będzie wzrastać (Ministerstwo Gospodarki 2021). Przykładowo trwa rozbudowa instalacji w Mszczonowie, Poddębicach, Uniejowie oraz Podhalu. W Toruniu trwa zagospodarowanie odwiertu. Poszukiwania na różnych stadiach zaawansowania trwają w Sieradzu, Sochaczewie, Kole, Lądku-Zdroju, Szaflarach i Tomaszowie Mazowieckim (Kępińska 2016). Optymalne wykorzystanie potencjału produkcyjnego tylko z planowanych odwiertów pozwoli całkowicie pokryć obecne zapotrzebowanie krajowe na lit.

Zgodnie z przytoczonymi danymi dotyczącymi gwałtownego wzrostu zapotrzebowania na lit w perspektywie najbliższych dziesięciu lat (Bobba i in. 2020), wynikającego w znacznej mierze z rozwoju elektromobilności, należy stworzyć możliwość ciągłych 
i niezależnych od importu dostaw tego surowca dla przemysłu w celu zapewnienia bezpieczeństwa produkcji oraz poprawy konkurencyjności. Obiecującym źródłem tego pierwiastka mogą okazać się wody termalne. Proces polega na jednoczesnej produkcji energii cieplnej (i/lub elektrycznej) oraz odzyskiwaniu soli litu z wychłodzonej solanki.

Na terenie Polski odnotowano przypadek wypływu solanki z otworu wiertniczego o zawartości litu wynoszącej 268 mg/l (Wachowiak i Kasprzak 2014), jednak przeciętnie zawartość tego pierwiastka waha się od kilku do kilkudziesięciu miligramów na litr roztworu. Jednocześnie, w związku z polityką ograniczania emisji dwutlenku węgla planuje się zwiększenie wykorzystania energii geotermalnej jako stabilnego i efektywnego ekonomicznie rozwiązania alternatywnego wobec paliw kopalnych. Na terenie Polski szczególnie dobre warunki do rozwoju tego typu instalacji są na terenie Niżu Polskiego. Jest to związane $\mathrm{z}$ istnieniem wysadów solnych o znacznie lepszej przewodności cieplnej od otaczających skał. Jednocześnie obecności soli kamiennej towarzyszy podwyższona zawartość litu, co wynika z warunków sedymentacji tego typu utworów. Te dwa czynniki (wzrost liczby projektów geotermalnych i ich lokalizacja w aspekcie geologicznym) oraz wzrost zapotrzebowania na lit sprawiają, że zasadne staje się podjęcie prób odzysku tego surowca $\mathrm{z}$ wód termalnych.

\section{Zastosowanie technologii membranowych w produkcji litu}

Jedną z najbardziej obiecujących metod odzysku litu ze złóż termalnych jest wykorzystanie membran, ponieważ możliwa jest ich instalacja w ciągu technologicznym ciepłowni oraz są łatwo skalowalne. Oziębiona solanka kierowana jest pod ciśnieniem do otworu chłonnego i jednocześnie może przepływać przez zestaw membran. Osiągane ciśnienia pozwalają na zastosowanie nanofiltracji, która odseparowuje większość jonów od kationów litu. Strumień następnie jest kierowany na kolejne moduły membranowe i po kilku operacjach dochodzi do wytrącania produktu końcowego. Nie istnieją jednak żadne komercyjne projekty wykorzystujące sekwencje wspomnianych technologii pozwalające pozyskiwać lit ze źródeł o stosunkowo niskiej zawartości.

Przekonanie o skuteczności proponowanej metody opiera się na właściwości membrany polegającej na coraz bardziej selektywnym zatrzymywaniu kationów przez membranę wraz ze wzrostem ich masy i ładunku (Rautenbach 1996), w związku z czym w warunkach nanofiltracji istnieje potwierdzona badaniami (Park i in. 2020) możliwość zatężenia solanki w jony litu. Ponadto instalacja geotermalna pracuje pod ciśnieniem wynoszącym kilkadziesiąt barów, co stanowi bardzo dobre warunki do przeprowadzania nanofiltracji i umożliwia migrację jonów wraz z wodą z koncentratu do permeatu. Dodatkowym atutem zastosowania tej technologii jest możliwość wykorzystania taniej oraz odnawialnej energii cieplnej pochodzącej z wód termalnych, niezbędnej do przeprowadzania destylacji membranowej. Dzięki temu możliwe jest zatężanie solanki i wy- 
trącanie niepożądanych substancji po ochłodzeniu roztworu. Opracowana w ramach badań sekwencja nanofiltracji i destylacji membranowej pozwoli na uzyskanie węglanu litu przy wykorzystaniu znacznie mniejszej ilości chemikaliów dzięki ograniczeniu liczby procesów pośrednich polegających na naprzemiennym wytrącaniu i rozpuszczaniu uzyskanej soli z wykorzystaniem innych związków chemicznych. Jednocześnie zastosowane technologie, dzięki ograniczeniu kontaktu z powietrzem oraz pracy w warunkach ciągłego przepływu umożliwiają ponowne wprowadzenie solanki (pozbawionej głównie litu) do złoża.

\subsection{Opracowanie technologii odzysku litu ze złóż termalnych}

Poniżej wymieniono kluczowe kroki w opracowaniu technologii odzysku litu ze złóż termalnych:

- Określenie efektywności zastosowania membran w procesie zwiększania koncentracji litu w solance pochodzącej z odwiertów geotermalnych. Należy określić zmiany stężeń jonów magnezu oraz litu podczas nanofiltracji dla różnych warunków przepływu. W szczególności istotne jest określenie optymalnej temperatury/ gradientu temperatury $\mathrm{w}$ procesie $\mathrm{w}$ aspekcie zapobiegania odkładania się osadów. W tym celu pomocne jest opracowanie przynajmniej modelu numerycznego, a w perspektywie analitycznego, pozwalającego na wyznaczenie optymalnej temperatury dla określonego stężenia jonów. Model taki może być użyteczny przy dalszej optymalizacji procesu odzysku litu dla złóż o różnej charakterystyce.

- Wskazanie najefektywniejszych parametrów membran (tj. rozmiar porów) w celu optymalizacji procesu zatężania solanki oraz określenie najefektywniejszej geometrii układu, czyli liczby stopni separacji.

- Zaprojektowanie oraz skonstruowanie układu zdolnego do zwiększenia koncentracji litu w warunkach przepływu. Układ taki stanowi podstawowy element instalacji badawczej procesu odzyskiwania litu. Dzięki niemu możliwe jest określenie docelowej metody separacji oraz parametrów pracy układu.

- Opracowanie ciągu technologicznego odzysku węglanu litu z solanki. Przy czym najistotniejszy element stanowi optymalizacja procesu wytrącania się węglanu litu z zatężonej solanki w kontekście minimalizacji użytych reagentów, jak również ich późniejszego odzysku.

- Opracowanie modelu teoretycznego oraz numerycznego opisującego degradację membran w trakcie procesu filtracji. Model taki pozwoli określi spodziewaną żywotność membran. W perspektywie należy opracować ciąg technologiczny ograniczający degradację membran w celu wydłużenia ich użytkowania.

- Budowa instalacji pilotowej do odzysku węglanu litu na odwiercie geotermalnym. Instalacja taka pozwoli dokładnie wyznaczyć koszty oraz efektywność zaprojektowanej technologii. 
Najistotniejszymi wskaźnikami efektywności potencjalnej metody są:

- czystość finalnego węglanu litu (produkt handlowy winien mieć czystość min $99,5 \%)$,

- wzrost stężenia litu w procesie nanofiltracji (co najmniej dziesięciokrotny wzrost w porównaniu z solanką z odwiertu),

- uzyskanie min. 20\% litu z teoretycznych zasobów przepływającej wody,

- zmniejszenie degradacji membrany przy użyciu antyskalantów o 50\% w stosunku do braku ich użycia.

\subsection{Opłacalność wdrożenia potencjalnej infrastruktury}

W tabeli 3 przedstawiono dwa scenariusze dotyczące zysków z zainstalowania układu pełnoskalowego na odwiercie TG1 w Toruniu. Przeprowadzone analizy pokazały, że zakładana wydajność produkcyjna węglanu litu z tego odwiertu wynosi 35 t/rok LCE, co stanowiłoby ponad 11\% krajowego zapotrzebowania na ten surowiec w roku 2020.

W pierwszym scenariuszu założono cenę 8 tys. USD za tonę węglanu litu, czyli przy kursie wymiany z dnia 12.03.2021 roku - około 30,8 tys. PLN. Założona cena produktu w tym przypadku stanowi przybliżoną cenę węglanu litu z ostatnich 10 lat. Przy takim założeniu roczny przychód ze sprzedaży wynosi około 700 tys. PLN. Główny koszt stanowi budowa instalacji - około 1 mln PLN. W scenariuszu tym założono 5-letnią żywotność instalacji, po tym czasie należy poddać ją modernizacji oraz wymienić zużyte podzespoły. Kolejnym kosztem jest zakup membran. Tu oszacowano koszt na około 300 tys. PLN przy założeniu 3-letniej żywotności membran, czyli ok. 100 tys. PLN/rok. Koszt odczynników, transportu oraz energii zużytej przez instalację oszacowano na 2 tys. PLN/t uzyskanego węglanu litu, czyli 70 tys. PLN/rok. Sumaryczny przychód $\mathrm{z}$ instalacji $\mathrm{w}$ ciągu zakładanych 5 lat funkcjonowania układu to 3,5 mln PLN. Zatem przy założeniu nakładów inwestycyjnych rzędu 1,85 mln PLN roczna stopa zwrotu wynosi $38 \%$. W celu porównania kosztów oraz marży dla przedstawianej technologii z obecnie stosowanymi rozwiązaniami w tabeli podano wskaźniki w odniesieniu do jednej tony produktu. Koszt wyprodukowania jednej tony produktu wynosi około 2,6 tys. USD/t LCE i jest porównywalny z kosztami produkcji w kopalniach spodumentu oraz o 50\% niższy niż koszt ekstrakcji solanek. Marża natomiast jest porównywalna z tą otrzymywaną dla kopalni, która w odniesieniu do cen z 2019 roku wynosiła 2,5 tys. USD/t LCE.

Drugi scenariusz zakłada cenę za tonę równą 13 tys. USD, co stanowi średnią cenę węglanu litu z ostatnich 5 lat. W tym przypadku w perspektywie 5-letniej istotnie podwyższa się przychód - do prawie $7 \mathrm{mln}$ PLN - przy takich samych kosztach inwestycyj- 
nych oraz eksploatacyjnych. Roczna stopa zwrotu jest na poziomie 75\%. Spodziewany przychód będzie dwa razy większy niż w przypadku scenariusza I. Natomiast marża wzrasta trzykrotnie. Marża w tym scenariuszu wynosi 7,8 tys. USD/t LCE. Jest ona wyższa niż spodziewana marża dla złóż solankowych w odniesieniu do cen z 2019 roku wynoszących 5 tys. USD/t LCE.

Tabela 3

Scenariusze opłacalności instalacji do odzyskiwania litu na odwiercie geotermalnym

\begin{tabular}{|c|c|}
\hline \multicolumn{2}{|l|}{ Scenariusz I } \\
\hline Wydajność [t/rok LCE] & 35 \\
\hline Cena za tonę [PLN/t LCE] & 30800 \\
\hline Przychód ze sprzedaży [PLN/rok] & 1078000 \\
\hline Początkowy koszt instalacji [PLN] & 1000000 \\
\hline Roczny koszt membran [PLN] & 100000 \\
\hline Roczny koszt utrzymania instalacji [PLN/rok] & 70000 \\
\hline Roczny przychód z instalacji [PLN] & 708000 \\
\hline Przychód po 5 latach inwestycji [PLN] & 3540000 \\
\hline \multicolumn{2}{|c|}{ Wskaźniki w odniesieniu do jednej tony produktu } \\
\hline Koszt $[\mathrm{PLN} / \mathrm{t}]$ & 10571 \\
\hline Przychód [PLN/t] & 20229 \\
\hline Marża $[P L N / t]$ & 9657 \\
\hline \multicolumn{2}{|l|}{ Scenariusz II } \\
\hline Wydajność [t/rok LCE] & 35 \\
\hline Cena za tonę [PLN/t LCE] & 50050 \\
\hline Przychód ze sprzedaży [PLN/rok] & 1751750 \\
\hline Początkowy koszt instalacji [PLN] & 1000000 \\
\hline Roczny koszt membran [PLN] & 100000 \\
\hline Roczny koszt utrzymania instalacji [PLN/rok] & 70000 \\
\hline Roczny przychód z instalacji [PLN] & 1381750 \\
\hline Przychód po 5 latach inwestycji [PLN] & 6908750 \\
\hline \multicolumn{2}{|c|}{ Wskaźniki w odniesieniu do jednej tony produktu } \\
\hline Koszt $[\mathrm{PLN} / \mathrm{t}]$ & 10571 \\
\hline Przychód [PLN/t] & 39479 \\
\hline Marża [PLN/t] & 28907 \\
\hline
\end{tabular}




\section{Podsumowanie}

Obecnie spodziewany jest znaczący wzrost popytu na lit. Jest to związane w szczególności z rozwojem transportu elektrycznego. Istnieją uzasadnione obawy, że wzrost podaży nie będzie nadążał za przewidywanym wzrostem popytu. Dotychczasowe technologie pozyskania litu koncentrują się w nielicznych rejonach świata i polegają na odparowywaniu wody z solanek w celu pozyskania tego cennego pierwiastka. Wiąże się to $\mathrm{z}$ bardzo dużą energochłonnością oraz degradacją środowiska.

Już teraz obserwuje się znaczący wzrost cen tego surowca. Może to mieć negatywny wpływ na rozwój transportu elektrycznego, a co za tym idzie - może spowodować niewywiązanie się z planowanej redukcji emisji $\mathrm{CO}_{2}$. Dodatkowo w Europie jest niewielu producentów litu. Znaczący wzrost popytu może nie tylko skutkować wzrostem cen, ale także przerwaniem lub zaburzeniem łańcucha dostaw litu do fabryk wytwarzających ogniwa. $\mathrm{Z}$ tego względu istotne staje się znalezienie innych niekonwencjonalnych sposobów pozyskiwania litu. W perspektywie jego źródłem mogą być wody termalne. Pod warunkiem rozwinięcia odpowiedniej technologii możliwe jest w przyszłości rozpoczęcie produkcji rodzimej litu. Przedstawione analizy pokazują jednak, że takie przedsięwzięcie może być opłacalne tylko jako infrastruktura towarzysząca istniejącym lub planowanym ciepłowniom geotermalnym.

Baza surowcowa umożliwi dalszy rozwój technologii bezemisyjnych w transporcie na terenie kraju. Dodatkowym atutem zastosowania tej technologii jest ograniczenie zużycia wody, ograniczenie emisji gazów cieplarnianych przy produkcji surowców oraz brak konieczności magazynowania solanki. Cały proces może odbywać się w ciągu technologicznym pozyskania ciepła z wód geotermalnych.

\section{Literatura}

Bi Q., Zhang Z., Zhao C., Tao Z., 2014, Study on the recovery of lithium from high $\mathrm{Mg}^{2+} / \mathrm{Li}^{+}$ratio brine by nanofiltration, Water Science and Technology, vol. 70(10), s. 1690-1694. https://doi.org/10.2166/wst.2014.426.

Bobba S., Carrara S., Huisman J., Mathieux F., Pavel C., 2020, Critical Raw Materials for Strategic Technologies and Sectors in the EU - A Foresight Study, European Commission, Brussels.

Calisaya-Azpilcueta D., Herrera-Leon S., Lucay F.A., Cisternas L.A., 2020, Assessment of the Supply Chain under Uncertainty: The Case of Lithium, Minerals, vol. 10(7), 604. https://doi.org/10.3390/min10070604.

Cermak V., 1993, Lithospheric thermal regimes in Europe, Physics of the Earth and Planetary Interiors, t. 79, s. 179-193. https://doi.org/10.1016/0031-9201(93)90147-2.

EuGeLi, 2021, EuGeLi project: Extracting european lithium for future electric vehicle batteries, https://www.eramet.com/en/activities/innovate-design/eugeli-project [dostęp: 19.10.2021]. 
European Commission, 2018, Commission staff working document Report on Raw Materials for Battery Applications, SWD(2018) 245/2.

Flexer V., Baspineiro C.F., Galli C., 2018, Lithium recovery from brines: A vital raw material for green energies with a potential environmental impact in its mining and processing, Science of the Total Environment, vol. 639, s. 1188-1204. https:// doi.org/10.1016/j.scitotenv.2018.05.223.

Główny Urząd Statystyczny (GUS), 2021, Obroty ogółem - wyszczególnienie według nomenklatury towarowej, http://swaid.stat.gov.pl/HandelZagraniczny_dashboards/ Raporty_konstruowane/RAP_SWAID_HZ_3_4.aspx [dostęp: 19.10.2021].

Hocking M., Kan J., Young P., Terry Ch., Begleiter D., 2016, Industry Lithium 101, Deutsche Bank, Markets Research, http://panopus.net/assets/files/160509-DeutschesBank-Welcome-to-the-Lithium-Ion-Age.pdf [19.10.2021].

Hummel P., Lesne D., Radlinger J., Golbaz Ch., Langan C., Takahashi K., Mulholland D., Stott A., Haire G., Mittermaier M., Gaudois N., Shaw L., 2017, UBS Evidence Lab Electric Car Teardown - Disruption Ahead, UBS Global Research, Q-Series, https://neo.ubs.com/shared/d1wkuDlEbYPjF/ [19.10.2021].

Jaskula B., 2020, Lithium Statistics and Information, USGS Science for a Changing World, https://www.usgs.gov/centers/nmic/lithium-statistics-and-information [dostęp: 19.10.2021].

Karlsruhe Institute of Technology, 2020, New Process Enables Lithium Mining in Germany, https://www.kit.edu/kit/english/pi_2020_054_new-process-enables-lithiummining-in-germany.php [dostęp: 19.10.2021].

Kępińska B., 2016, Przegląd stanu wykorzystania energii geotermalnej w Polsce w latach 2013-2015, Technika Poszukiwań Geologicznych, R. 55, nr 1, s. 19-35.

Koning A., de, Kleijn R., Huppes G., Sprecher B., van Engelen G., Tukker A., 2018, Metal supply constraints for a low-carbon economy?, Resources Conservation and Recycling, vol. 129, s. 202-208. https://doi.org/10.1016/j.resconrec.2017.10.040.

Li J., Wang M., Zhao Y., Yang H., Zhong Y., 2018, Enrichment of lithium from salt lake brine by forward osmosis, Royal Society open science, vol. 5(10), 180965. https:// doi.org/10.1098/rsos.180965.

Li X., Mo Y., Qing W., Shao S., Tang C.Y., Li J., 2019. Membrane-based technologies for lithium recovery from water lithium resources: A review, Journal of Membrane Science, vol. 591, 117317. https://doi.org/10.1016/j.memsci.2019.117317.

Ministerstwo Gospodarki, 2021. Polityka energetyczna Polski do 2040 roku, https:// www.gov.pl/web/klimat/polityka-energetyczna-polski [dostęp: 19.10.2021].

Park S.H., Kim J.H., Moon S.J., Jung J., Wang H., Aamer A., Quist-Jensen C.A., Macedonio F., Drioli E., Lee Y., 2020, Lithium recovery from artificial brine using energy-efficient membrane distillation and nanofiltration, Journal of Membrane Science, vol. 598, 117683. https://doi.org/10.1016/j.memsci.2019.117683. 
Rautenbach R., 1996, Procesy membranowe, Wydawnictwa Naukowo-Techniczne, Warszawa.

S\&P Global Market Intelligence, 2021, Lithium Sector: Production Costs Outlook, https://pages.marketintelligence.spglobal.com/lithium-sector-production-costsoutlook-MS.html [dostęp: 19.10.2021].

Sun S.-Y., Cai L.-J., Nie X.-Y., Song X., Yu J.-G., 2015, Separation of magnesium and lithium from brine using a Desal nanofiltration membrane, Journal of Water Process Engineering, vol. 7, s. 210-217. https://doi.org/10.1016/j.jwpe.2015.06.012.

Uliasz-Misiak B., Winid B., 2018, Brines from the Mesozoic formations of northern and central Poland as a prospective source of chemical raw materials, Gospodarka Surowcami Mineralnymi - Mineral Resources Management, t. 37, z. 2, s. 5-20. https://doi.org/10.24425/118655.

Wachowiak J., Kasprzak A., 2014, Charakterystyka mineralogiczna, geochemiczna i izotopowa solanki z samo-wyplywu z otworu M-32 w wysadzie solnym Mogilno, Przegląd Solny, t. 10, s. 39-48.

Yaroshchuk A., Bruening M.L., Zholkovskiy E., 2019, Modelling nanofiltration of electrolyte solutions, Advances in Colloid and Interface Science, vol. 268, s. 39-63. https://doi.org/10.1016/j.cis.2019.03.004. 